INTIQAD: JURNAL AGAMA DAN PENDIDIKAN ISLAM

ISSN 1979-9950 (print) || ISSN 2598-0033 (online), http://jurnal.umsu.ac.id/index.php/intiqad

DOI: 10.30596/intiqad.v\% vi\%i.4456

Vol. 12, No. 1 (June 2020)

\title{
Reduksi Perilaku Bolos Sekolah (Studi Tentang Kerja Sama Guru PAI dan IPS di MTs PAI Medan)
}

\author{
Rahmat Rifai Lubis*1, Rasyid Anwar Dalimunthe², Ruslan Efendi ${ }^{3}$ \\ STAI Sumatera Medan*1 \\ STAI Serdang Lubuk Pakam ${ }^{2}$ \\ STAI Aceh Tamiang ${ }^{3}$ \\ *1email: pailubis8@gmail.com \\ ${ }^{2}$ email: rasyid.a.dalimunthe@staiserdanglubukpakam.ac.id \\ 3 email: ruslanefendi420@gmail.com
}

\begin{abstract}
This study aims to analyze (1) the background of the emergence of school skipping behavior, (2) the collaboration pattern of social studies teachers and PAI in overcoming school skipping behavior, (3) the obstacles faced in overcoming these behaviors. The research method used is qualitative with a case study approach. Data collection through observation, interviews, and documentation. The results showed that there are two underlying factors, namely internal factors, such as laziness in learning, dislike learning, feeling unimportant with learning, inability to participate in learning, mistakes in learning orientation. While external factors include the influence of friends, internet addiction, discomfort with teachers, loss of family control, neighborhood. The pattern of cooperation is to provide guidance, make a program of activities ' I'm ashamed to skip school', Working together in designing learning material formulations, applying cognitive moral strategies, engineering the environment and school relationships, limiting student relationships, establishing cooperation with parents, giving punishment. The obstacles faced are the lack of parental attention, lack of household harmony, the difficulty of providing awareness to the local community
\end{abstract}

Keywords: Skipping School, Reduction, IPS, PAI

\section{Artikel Info}

Received:

28 March 2020

Revised:

10 April 2020

Accepted:

02 May 2020

Published:

04 June 2020

\begin{tabular}{l}
\hline \multicolumn{1}{c}{ Abstrak } \\
\hline Penelitian ini bertujuan untuk menganalisis (1) latar \\
belakang timbulnya perilaku bolos sekolah, (2) pola \\
kerjasama guru IPS dan PAI dalam mengatasi perilaku bolos \\
\hline \hline
\end{tabular}


sekolah, (3) kendala yang dihadapi dalam mengatasi perilaku tersebut. Metode penelitian yang digunakan ialah kualitatif dengan pendekatan studi kasus. Pengumpulan data melalui observasi, wawancara, dan dokumentasi. Hasil penelitian menunjukan bahwa terdapat dua faktor yang melatar belakangi yakni faktor internal, seperti sifat malas mengikuti pembelajaran, tidak menyukai pembelajaran, merasa tidak penting dengan belajar, ketidak sanggupan mengikuti pembelajaran, kekeliruan dalam orientasi belajar. Sedangkan faktor eksternal meliputi pengaruh teman, Kecanduan internet, ketidaknyamanan dengan guru, lepas kontrol keluarga, lingkungan tempat tinggal. Adapun pola kerjasamanya yakni memberikan bimbingan, membuat program kegiatan 'aku malu bolos sekolah', Bekerja sama dalam mendesain formulasi materi pembelajaran, Penerapan strategi moral kognitif, merekayasa lingkungan dan pergaulan sekolah, membatasi pergaulan siswa, menjalin kerja sama dengan orang tua, memberikan punishment. Adapun kendala yang dihadapi ialah kurangnya perhatian orang tua, kurangnya keharmonisan rumah tangga, sulitnya memberikan kesadaran kepada masyarakat setempat

Kata Kunci: Bolos Sekolah, Reduksi, IPS dan PAI.

\section{A. Pendahuluan}

Orang tua tentu menginginkan anaknya kelak menjadi orang yang sukses, dan berguna baik bagi nusa, bangsa, dan agama. Karena itu lah untuk mencapainya orang tua pun berusaha semaksimal mungkin untuk menyekolahkan anaknya sampai pada jenjang yang tertinggi. Segala daya dan upaya diusahakan, mulai dari berkerja keras, membangun relasi, dan sampai mengorbankan diri sendiri (Erzard, 2018). Itu sebabnya sering terlihat banyak orang tua yang demi pendidikan anaknya banyak kehilangan harta, waktu, pikiran, bahkan tak sedikit dari mereka berujung pada kondisi sakit (Jailani, 2014).

Jika dianalisis sebenarnya hal ini bukanlah semata-mata karena ambisius orang tua akan kesuksesan anaknya di masa yang akan datang, akan tetapi di dalam Agama Islam memanglah orang tua diperintahkan untuk mendidik anakanaknya, bahkan dalam literatur Hadits disebutkan bahwa mendidik anak itu merupakan kewajiban yang melekat pada orang tua sejak anak tersebut 
ISSN 1979-9950 (print) || ISSN 2598-0033 (online), http://jurnal.umsu.ac.id/index.php/intiqad

DOI: 10.30596/intiqad.v\% vi\%i.4456

Vol. 12, No. 1 (June 2020)

dilahirkan. Bukan hanya bagi sang ayah saja, melainkan juga bagi sang ibu. Itu sebabnya dalam Islam kehadiran seorang anak, bukan sekedar pemberian dari Allah, melainkan amanah yang harus dijaga dan ditunaikan hak-haknya (Siregar, 2016).

Mendidik anak tentu bukanlah hal yang mudah, apalagi pada era milenial ini. Dibutuhkan metode dan strategi yang tak biasa, yang sesuai dengan zaman mereka. Orang tua-pun menjadi lebih ekstra menguras tenaganya untuk mendidik anak-anak mereka. Menghalangi anak untuk tidak ikut ambil bagian di zaman ini bukanlah metode yang tepat, sebab ia akan ketinggalan zaman dan informasi, sehingga mempersulit dirinya untuk dapat berkompetisi di era sekarang ini (Barni, 2019). Memberikannya kebebasanpun juga bukan metode yang tepat sebab anak akan menjadi lepas kontrol dan lupa diri. Intinya orang tua harus terampil dalam menghadapi dan mencari solusi dari setiap permasalahan anak (Lubis, 2019).

Era milenial ditandai dengan era dimana kecanggihan teknologi dan informasi menjadi ciri utamanya. Dengan adanya kecanggihan tersebut semakin memudahkan orang untuk mengakses segala informasi, baik yang berada di sekitar maupun yang berada di luar negeri. Itu sebabnya anak-anak pada masa ini kerap lebih akrab bergaul dengan internet dibandingkan dengan bergaul dengan teman-teman dan masyarakat. Tidak hanya itu mereka lebih menghabiskan waktunya di dunia maya ketimbang di dunia nyata. Tak sedikit dari mereka yang banyak tak pulang dari dunia mayanya ke dunia nyata, dalam arti memutuskan pergaulan nyata dan beralih ke dunia maya (Nata, 2018).

Era milenial diakui memang banyak memberikan manfaat positif terhadap perkembangan anak, tetapi tak dapat juga dipungkiri bahwa kehadirannya juga memberikan dampak negatif. Salah satunya ialah kebiasaan bolos (libur) sekolah. Disebut kebiasaan karena perilaku ini tidak dilakukan hanya sekali, namun berulang-ulang kali. Munculnya kebiasaan ini salah satu diantaranya disebabkan oleh ketidakmampuan anak untuk lepas dari dunia maya (media sosial, game online, social chat) sehingga menyebabkan kecanduan yang sulit untuk mereka tinggalkan. Akhirnya mereka memilih 
INTIQAD: JURNAL AGAMA DAN PENDIDIKAN ISLAM

ISSN 1979-9950 (print) || ISSN 2598-0033 (online), http://jurnal.umsu.ac.id/index.php/intiqad

DOI: 10.30596/intiqad.v\% vi\%i.4456

Vol. 12, No. 1 (June 2020)

untuk lebih lama dengan dunia maya

Belakangan ini banyak sekali

ketimbang dengan dunia nyatanya. pemberitaan di televisi yang

Bahkan karena rasa candu dan ketagihan tersebut membuat mereka lupa dengan jadwal sekolahnya. Bahkan tak sedikit dari mereka yang rela meninggalkan sekolahnya hanya untuk urusan-urusan dunia maya mereka (Lubis, Strategi Mendidik Akhlak Anak di Zaman Modern (Studi Pemikiran Nasih 'Ulwān Dalam Kitab Tarbiyatul Aulād), 2018).

Sebenarnya jika dianalisis lebih jauh lagi, kecanduan dengan dunia maya bukanlah faktor utamanya yang menyebabkan siswa bolos sekolah, namun runtutan dari kecanduanlah yang membuat mereka bolos sekolah. Runtutan kecanduan sosial itu dapat menjalar pada perilaku-perilaku menyimpang lainnya seperti hubungan seks di luar nikah, mengkomsumsi narkoba, perilaku premanisme dan anarkisme, dan tak menutup kemugkinan juga terikut dalam jaringan radikal yang pola rekrutmennya mengandalkan jaringan internet. Perilaku-perilaku yang muncul itu akan hilang manakalah orang tua dapat menjadi pengawas (supervisor) bagi perkembanan anak-anaknya (Salainty \& Rondonuwu, 2015). menampilkan kenakalan-kenakalan siswa dan uniknya kenakalan tersebut bermuara dari satu penyebab yang sama yakni bermula dari internet dan media sosial. Bahkan banyak para pemuda yang terjerumus ikut dalam jaringan radikal, yang bermula direkrut dari dunia maya. Walaupun tidak seluruhnya kebiasaan bolos sekolah dikarenakan aktivitasnya di media sosial, tetapi paling tidak ini menjadi salah satu faktor, bahkan merupakan faktor terbesar dan utama (Rahmawati, 2018).

Kebiasaan bolos sekolah tentu membuat resah orang tua, sebab ini bukan saja menyakitkan perasaan mereka, melainkan juga menjadi kekhawatiran di hati para orang tua tentang masa depan anak-anaknya. Semakin sering anak tidak masuk sekolah tentu akan menyebabkan dirinya ketertinggalan materi pelajaran. Ketertinggalan materi pelajaran tentu berdampak pada ketuntasan hasil belajarnya. Jika hasil belajar tidak tuntas tentu menurunkan prestasi, dan tingkat perkembangan perilaku (kognitif, afektif, dan psikomotorik) peserta didik. Bahkan lebih jauh jika mau dikaitkan akan 
INTIQAD: JURNAL AGAMA DAN PENDIDIKAN ISLAM

ISSN 1979-9950 (print) || ISSN 2598-0033 (online), http://jurnal.umsu.ac.id/index.php/intiqad

DOI: 10.30596/intiqad.v\% vi\%i.4456

Vol. 12, No. 1 (June 2020)

berpengaruh pada spritualnya (Lubis, Optimalisasi Kecerdasan Spiritual Anak, 2018).

Termasuk juga guru yang menjadi resah dengan hal ini, sebab sudah menjadi tanggung jawab guru untuk membuat siswa betah dan merasa ketergantungan dengan belajar.

Dikatakan demikian sebab bisa saja memang penyebab bolos sekolah itu karena ketidaknyamanan dalam kelas, atau mungking terganggu karena hal-hal yang berkaitan dengan aspek pergaulan.

Oleh karena itu memanglah sangat diperlukan komunikasi yang dekat antara guru dan siswa untuk dapat memahami problematika yang sedang dihadapi siswa sehingga dapat mencegah perilaku membolos tersebut. Tidaklah salah jika identifikasi karakteristik siswa sangat diperlukan oleh guru, dengan demikian guru dapat mengetahui sifat dan karakter siswanya (Lubis, Strategi Mendidik Akhlak Anak di Zaman Modern (Studi Pemikiran Nasih 'Ulwān Dalam Kitab Tarbiyatul Aulād), 2018).

Perilaku membolos ini jika dibiarkan akan memberikan dampak besar terhadap komptensi dan karakter siswa, untuk itulah institusi pendidikan perlu untuk memberikan perhatian yang serius dalam hal ini. Tentu yang paling memiliki wewenang dan tanggungjawab dalam hal ini ialah konselor. Ia memiliki tugas untuk memberikan bimbingan dan pendampingan kepada klien (siswa) agar tersadarkan dan meninggalkan perilaku negatif. Tentu bukanlah pekerjaan mudah untuk mengembalikan mereka kepada perilaku yang bernar. Tidak dapat satu hari, mungkin beberapa hari atau bahkan sampai dengan waktu yang berkala untuk dapat mengembalikannya dengan normal (Novarita, 2014).

Bagi sekolah yang memiliki konselor tentu perilaku-perilaku menyimpang siswa tidaklah menjadi kendala berarti, dalam arti sudah ada yang bertanggung jawab dalam menanganinya. Tetapi bagi sekolah yang tidak memilikinya tentu akan menimbulkan masalah baru. Biasanya sekolah yang tidak memiliki konselor akan muncul dua bentuk respon dalam menyikapi perilaku-perilaku menyimpang peserta didik (termasuk dalam hal ini bolos sekolah) yakni tidak mau peduli (karena menganggap bukan tugasnya), dan saling menyalahkan antar guru bidang studi. Dan bahkan yang lebih sering dipersalahkan ialah guru Pendidikan Agama Islam dan guru Ilmu 
ISSN 1979-9950 (print) || ISSN 2598-0033 (online), http://jurnal.umsu.ac.id/index.php/intiqad

DOI: 10.30596/intiqad.v\% vi\%i.4456

Vol. 12, No. 1 (June 2020)

Pengetahuan Sosial. Mempersalahkan mereka sebenarnya tidaklah sepenuhnya tepat, sebab tentu keduanya lebih bertangung jawab dalam aspek pembelajaran (Afrilian, 2017).

Kondisi

permasalahan

sebagaimana disebutkan di atas persis seperti permasalahan yang sedang dihadapi oleh MTs. Pendidikan Agama Islam (PAI). Terdapat beberapa siswa yang memiliki kebiasaan dalam bolos sekolah, bahkan terkadang pergi dari rumah tetapi tidak sampai ke madrasah. Perilaku bolos sekolah mungkin bukanlah masalah yang baru di sekolahsekolah lainnya. Tetapi perilaku di sekolah ini menjadi menarik untuk diteliti sebab kejadian biasa ini dapat menjadi masalah serius sebab madrasah tersebut tidaklah memiliki konselor, yang khusus untuk menangani hal tersebut. Maka menyikapi hal tersebut guru IPS dan PAI lah yang bekerja sama untuk menuntaskan penyimpangan tersebut. Selain itu kenunikan lainnya, jika sekolah-sekolah lain memilih untuk memecat siswa yang sering bolos, namun sekolah ini lebih memilih untuk mempertahankannya.

Sebenarnya penelitian-penelitian lain tentang hal ini sudah pernah dilakukan, tetapi hanya sebatas tentang mengetahui faktor-faktor penyebabnya saja seperti penelitian yang dilakukan oleh Annisa Damayanti pada tahun 2013, dengan judul Studi tentang Perilaku Membolos pada Siswa SMA Swasta di Surabaya. Hasil penelitian menunjukkan bahwa Faktor penyebab bolos pada siswa tersebut dikarenakan beberapa hal yakni permasalahan yang berasal dari diri sendiri, faktor keluarga, dan faktor sekolah dengan pola perilaku membolos yaitu bermain playstation atau internet di warnet, nongkrong, berkumpul bersama teman yang suka membolos. Hasil penelitian ini menyatakan bahawa perilaku membolos dapat mempengaruhi akademik di sekolah, karena tidak dapat menyelesaikan topik matapelajaran pada hari itu juga (Damayanti \& Setiawati, 2013). Sedangkan penelitian yang sedang dibahas ini lebih fokus kepada bentuk kerja sama yang dilakukan oleh guru-gutu IPS dan PAI di MTs. Pendidikan Agama Islam dalam menyikapi kebiasaan menyimpang yakni bolos sekolah. Walaupun tentu saja mulanya akan dipaparkan terlebih dahulu faktor-faktor yang melatar 
ISSN 1979-9950 (print) || ISSN 2598-0033 (online), http://jurnal.umsu.ac.id/index.php/intiqad

DOI: 10.30596/intiqad.v\% vi\%i.4456

Vol. 12, No. 1 (June 2020)

belakangi terjadinya penyimpangan

tersebut.

Riset ini memiliki manfaat yang signifikan, terutama kepada pihak sekolah MTs PAI Medan, sehingga bisa lebih meningkatkan perhatian terhadap kondisi perilaku anak yang menyimpang tersebut. Manfaat lainnya, hasil penelitian ini dapat dijadikan sebagai bahan masukan dan referensi bagi sekolah-sekolah lain yang pada institusinya tidak memiliki guru bimbingan konseling. Dan juga menjadi masukan bagi guru Pendidikan Agama Islam dan IPS dalam bekerja sama untuk hal perilaku bolos siswa.

Berdasarkan permasalah di atas maka dapatlah dirumuskan beberapa permasalahan yakni 1) Apakah yang melatarbelakangi timbulnya perilaku bolos sekolah, 2) bagaimana pola kerja sama guru IPS dan PAI dalam menangani perilaku tersebut, 3) apa sajakah kendala yang dihadapi dalam memperbaiki perilaku tersebut. Adapun tujuan penelitiannya ialah untuk menganalisis latar belakang timbulnya perilaku bolos, strategi mengatasinya (pola kerja sama guru IPS dan PAI dan juga kendala yang dihadapi selama menangani perilaku tersebut.

\section{B. Metode Penelitian}

\section{Lokasi dan Waktu Penelitian Penelitian}

Penelitian ini dilaksanakan di MTs. Pendidikan Agama Islam (PAI) yang beralamat di Jalan Pendidikan Gg, Tertib No. 8 Medan Timur. MTs. Ini berstatus Swasta, di bawah naungan Yayasan Pendidikan Agama Islam. MTs ini terbilang sebagai madrasah tertua di antara madrasah-madrasah yang ada di Kecamatan Medan Timur. Alasan pemilihan lokasi penelitian ini karena di madrasah ini memang setiap tahun pelajarannya selalu ada saja yang memiliki perilaku bolos, walaupun setiap tahun jumlahnya tidaklah selalu sama. Pada tahun ini terdapat 5 orang siswa dari seluruh kelas (VII, VIII, IX) yang berperilaku demikian. Dan hal ini terbilang sudah cukup lama dan dapat disebut menjadi kebiasaan mereka. Seperti yang telah disebutkan di atas bahwa pihak sekolah tidaklah mengambil langkah pemecatan seperti layaknya yang dilakukan oleh sekolahsekolah lainnya. Sekolah lebih memilih untuk mempertahankannya dengan alasan keprihatinan, dan kekhawatiran 
ISSN 1979-9950 (print) || ISSN 2598-0033 (online), http://jurnal.umsu.ac.id/index.php/intiqad

DOI: 10.30596/intiqad.v\% vi\%i.4456

Vol. 12, No. 1 (June 2020)

akan tidak adanya sekolah yang mau menerima anak tersebut jika dipecat.

Alasan lain pemilihan lokasi ini, karena di sekolah tersebut sampai dengan saat ini tidaklah tersedia guru Bimbinan Konseling (BK), sehingga menambah semakin unik bagaimana mereka mengatasi perilaku-perilaku menyimpang tersebut (bolos sekolah). Tentu ini bukanlah kerja satu guru, sebab jika satu guru mungkin akan menguras banyak tenaga dan pikiran, dan setelah proses pengamatan awal ternyata guru PAI dan IPS yang saling bekerja sama dalam hal ini.

Adapun waktu penelitian dilaksanakan mulai dari bulan Oktober hingga Desember 2019. Waktu tersebut terbagi untuk kegiatan perencanaan penelitian, pelaksanaan penelitian, hingga penulisan laporan penelitian. Pengumpulan data di lapangan dilakukan di sela-sela jam istirahat para subjek penelitian, atau berkisar pada saat jam istirahat pertama (09.50-10.05 Wib) dan jam istirahat kedua (11.5-11.30). Namun kadang kala juga dilakukan di saat jam pulang sekolah, hal ini dilakukan untuk tidak menggangu aktivitas mengajar guru dan belajar siswa.

\section{Subjek Penelitian}

Adapun yang menjadi subjek dalam penelitian ini ialah siswa MTs. PAI yang memiliki perilaku bolos sekolah, guru Pendidikan Agama Islam dan guru Ilmu Pengetahuan Sosial, dan juga Kepala Sekolah. Sebagaimana yang telah disinggung di atas bahwa jumlah siswa yang memiliki kebiasaan membolos yakni 5 siswa. Jumlah tersebut tidaklah untuk satu kelas melainkan untuk keseluran kelas. Jumlah tersebut berdasarkan data wawancara awal dengan Kepala Sekolah, dan juga berdasarkan absen yang telah diamati. Di madrasah ini hanya terdapat satu guru Pendidikan Agama Islam (Aqidah Akhlak, Alquran Hadis, Fikih, dan SKI) dan Satu guru Ilmu Pengetahuan Sosial, maka dalam hal ini mereka berdualah yang akan menjadi subjek penelitian. Kemudian jika biasanya di berbagai sekolah atau madrasah, kepala madrasah dibagi menjadi tiga yakni bidang kurikulum, administrasi dan bidang kesiswaan. Lain halnya dengan di sekolah ini. Mengingat jumlah siswa yang tidak begitu banyak maka pimpinan madrasah hanya satu saja, yakni Kepala Sekolah. Dengan demikian kepala sekolah memiliki tugas yang rangkap.

\section{Metode dan Pendekatan Penelitian}


INTIQAD: JURNAL AGAMA DAN PENDIDIKAN ISLAM

ISSN 1979-9950 (print) || ISSN 2598-0033 (online), http://jurnal.umsu.ac.id/index.php/intiqad

DOI: 10.30596/intiqad.v\% vi\%i.4456

Vol. 12, No. 1 (June 2020)

Metode yang dipergunakan dalam penelitian ini yakni kualitatif. Penelitian kualitatif berusaha untuk menggali informasi dari berbagai peristiwa, atau fenomena kemudian mendeskripsikannya ditambah dengan analisis dan interpretasi peneliti. Metode penelitian kualitatif biasanya menelaah sesuatu yang belum ada, sehingga kerap penelitian kualitatif diangap menghasilkan teori baru. Secara ringkas penelitian ini akan mengupayakan untuk menggambarkan dan melukiskan kondisi objek penelitian pada saat ini sebagaimana adanya dengan didasarkan fakta-fakta di lapangan (Moleong, 2008).

Adapun pendekatan penelitian yang digunakan ialah pendekatan studi kasus. Pendekatan ini berupaya dalam mendeskripsikan dan merincikan secara kompleks tentang kasus dari berbagai dimensi. Teori studi kasus yang digunakan ialah 'a bouded sysem' (sistem keterikatan). Teori ini mengemukakan bahwa biasanya kasus itu tidaklah berdiri sendiri melainkan bekerja atas komponen-komponen lain atau dengan kata lain secara sistem yang terintegratif dan terpola (Stake, 1995). Ringkasnya teori ini menghendaki peneliti untuk tidak hanya berpijak pada satu kasus melainkan harus memahami kasus-kasus lain yang berkaitan dengan kasus utama. Tentu dalam penelitian ini kasus utamanya ialah kasus kebiasaan bolos sekolah. Kasus itu akan dipandang sebagai kasus yang kemunculannya dilatarbelakangi oleh berbagai macam kasus lainnya.

\section{Pengumpulan data}

Pengumpulan data dilakukan melalui metode observasi, wawancara, dan dokumentasi. Observasi dilakukan untuk pembahasan sesuai dengan hipotesis dan hasil hasil-hasil temuan penelitian yang diulas secara ilmiah. Menuliskan temuan-temuan ilmiah (scientific finding) yang diperoleh dari hasil-hasil penelitian yang telah dilakukan tetapi harus didukung oleh data-data yang memadai. Temuan ilmiah yang dimaksud di sini adalah bukan data-data hasil penelitian yang diperoleh.

Selain itu, harus dijelaskan juga perbandingannya dengan hasil-hasil para peneliti lain yang hampir sama topiknya. Hasil-hasil penelitian dan temuan harus dapat menjawab hipotesis penelitian di bagian pendahuluan, mengamati perilaku menyimpang siswa, dan mengamati langsung pola-pola kerja sama guru IPS dan PAI dalam mengatasi penyimpangan 
INTIQAD: JURNAL AGAMA DAN PENDIDIKAN ISLAM

ISSN 1979-9950 (print) || ISSN 2598-0033 (online), http://jurnal.umsu.ac.id/index.php/intiqad

DOI: 10.30596/intiqad.v\% vi\%i.4456

Vol. 12, No. 1 (June 2020)

perilaku tersebut. Wawancara dilakukan untuk memproleh informasi dari guru, siswa, dan juga Kepala Sekolah terkait dengan semua hal yang ada hubungannya dengan kebiasan membolos. Sedangkan dokumentasi digunakan untuk melihat rekam jejak siswa baik dari catatan kelas guru, dan juga absensi kehadirannya.

\section{Analisis data}

Analisis data dilakukan melalui tahapan (1) reduksi data pengurangan data dari keseluruhan data yang telah diperoleh dengan pertimbangan data yang relevan dengan penelitian. (2) analisis, yakni menganalisis data yang telah direduksi tersebut. Dengan melihat korelasi dan keterkaitan data. (3) interpretasi, yaitu memberikan interpretasi terhadap data yang telah dianalis, (4) konklusi, yaitu memberikan kesimpulan dari semua yang telah diinterpretasikan.

\section{Prosedur Penelitian}

Prosedur penelitian yang digunakan dalam penelitian kualitatif dengan pendekatan studi kasus ini merujuk pada teori John W. Creswell, menurutnya ada beberapa langkah yang harus dilalui: a. Prosedur pertama, menentukan pertanyaan yang akan dijadikan kasus, langkah ini bermaksud untuk memilih kasus utama dan memfokuskan topik sehingga dapat menelusuri kasus yang berkaitan dan juga agar hasil penelitian tetap fokus pada kasus yang telah ditetapkan dan tidak melebar.

b. Prosedur kedua, mengidentifikasi kasus, dengan maksud untuk mengetahui komponen-komponen yang berkaitan seperti individu, program, atau kegiatan. Dengan adanya ini nantinya akan dapat ditentukan jenis dari studi kasus yang digunakan.

c. Prosedur ketiga, pengumpulan data. Pengumpulan data dalam penelitian studi kasus biasanya luas, dan menggunakan berbagai sumber informasi, seperti pengamatan, wawancara, dokumentasi.

d. Prosedur keempat, analisis data dilakukan dengan melalui empat tahapan penentuan kategori, interpretasi, membentuk pola, dan mengembangkan generalisasi (Creswell, 2007). 
INTIQAD: JURNAL AGAMA DAN PENDIDIKAN ISLAM

ISSN 1979-9950 (print) || ISSN 2598-0033 (online), http://jurnal.umsu.ac.id/index.php/intiqad

DOI: 10.30596/intiqad.v\% vi\%i.4456

Vol. 12, No. 1 (June 2020)

C. Hasil Dan Pembahasan

1. Perilaku Menyimpang Siswa (Bolos) dan Faktor yang Melatarbelakanginya

Secara umum perilaku bolos sekolah itu ialah perilaku tidak masuk sekolah atau ketidakhadiran mengikuti pembelajaran tanpa memberi izin dan tanpa ada sesuatu hal yang menghalangi. Dengan kata lain perilaku bolos sekolah ini merupakan unsur kesengajaan siswa, dan umumnya dilakukan secara sembunyi-sembunyi atau tidak diketahui oleh orang lain. Perilaku bolos sekolah ini memilki dua model, pertama sama sekali tidak pergi dari rumah untuk datang ke sekolah. Kedua, pergi dari rumah untuk sekolah bahkan sesudah mengenakan baju sekolah tetapi tidak hadir mengikuti pembelajaran (Putri, Daharnis, \& Zikra, 2017).

Ketidakhadiran siswa mengikuti pembelajaran ini disebut dengan perilaku yang menyimpang sebab perilaku yang tidak sesuai dengan aturan, menunjukkan sikap ketidakdisiplinan siswa. Selain itu disebut menyimpang karena perilaku ini merupakan perilaku negatif yang bukan hanya merugikan diri sendiri, tetapi merugikan orang tua, guru, sekolah, bahkan teman-teman lainnya.
Merugikan diri sendiri sebab siswa akan ketinggalan pelajaran, merugikan orang tua sebab menimbulkan rasa sedih dan malu melihat perilaku anaknya, merugikan guru sebab merasa tidak dihargai dan tidak dihormati, bagi sekolah membuat citra sekolah semakin bertambah buruk, dan bagi teman-teman dapat menjadi wabah yang dapat menular kepada siapapun (Destiana, 2016).

Perilaku ini bukan hanya bertentangan dengan peraturan sekolah saja, melainkan juga bertentangan dengan moral masyarakat, dan juga ajaran agama Islam. Perilaku ini bertentangan bukan hanya karena perilaku tidak mengikuti pembelajarannya, tetapi dari perilaku ini akan lahir sifat ketidakjujuran, sifat tidak menghormati, dan menghargai, sifat membangkang, sifat premanisme, sikap egois, bahkan sampai mengalami gangguan jiwa.

Secara sosial perilaku ini tentu perilaku yang bertentangan dengan norma masayarakat. Siswa-siswa yang bolos sekolah kerap melakukan hal-hal yang terkadang di luar batas moral masyarakat, sehingga tak sedikit dijumpai mereka yang berbuat anarkis, 
INTIQAD: JURNAL AGAMA DAN PENDIDIKAN ISLAM

ISSN 1979-9950 (print) || ISSN 2598-0033 (online), http://jurnal.umsu.ac.id/index.php/intiqad

DOI: 10.30596/intiqad.v\% vi\%i.4456

Vol. 12, No. 1 (June 2020)

dan premanisme. Pada akhirnya

membuat masyarakat menjadi resah.

Perilaku menyimpang bolos sekolah bukanlah terbilang perilaku baru di kalangan siswa. Perilaku ini sudah sejak lama terjadi, bahkan sampai dengan saat ini perilaku ini tetap ada bahkan semakin meningkat. Walaupun terbilang problem klasik tetapi permasalahan ini juga tak sepenuhnya dapat diatasi hingga kini. Masih banyak di antara sekolah-sekolah yang merasa kesulitan mengatasi hal yang demikian.

Khusus di MTs. Pendidikan Agama Islam Medan, hasil wawancaran penulis dengan siswa dan guru bahwa yang menyebabkannya terjadi ada dual, yakni faktor internal siswa, dan faktor eksternal. Internal berarti berasal dari dalam diri siswa, sedangkan eksternal berasal dari luar diri siswa. Dalam hal ini wawancara dilakukan terhadap 5 orang anak yang memiliki kebiasaan bolos, namun sesuai etika kelima nama anak tersebut tidak akan disebut dalam penelitian ini. Untuk lebih memudahkan pembahasan akan dipaparkan dalam bentuk tabel, yakni:

Tabel 1. Latar Belakang Bolos

\begin{tabular}{|l|c|c|cc|}
\hline No & Faktor & $\begin{array}{c}\text { Latar } \\
\text { Belakang }\end{array}$ & \multicolumn{2}{|c|}{$\begin{array}{c}\text { Hasil } \\
\text { Wawancara }\end{array}$} \\
\hline & & Sifat malas & 3 orang siswa \\
\hline
\end{tabular}

\begin{tabular}{|c|c|c|c|}
\hline \multirow{5}{*}{1} & \multirow{5}{*}{ Internal } & $\begin{array}{l}\text { untuk } \\
\text { mengikuti } \\
\text { pembelajar } \\
\text { an }\end{array}$ & $\begin{array}{l}\text { menyatakan } \\
\text { bosan mengikuti } \\
\text { pembelajaran, } \\
\text { dan } 2 \text { orang siswa } \\
\text { merasa lelah } \\
\text { mengikuri } \\
\text { pembelajaran }\end{array}$ \\
\hline & & $\begin{array}{l}\text { Tidak } \\
\text { menyukai } \\
\text { pembelajar } \\
\text { an }\end{array}$ & 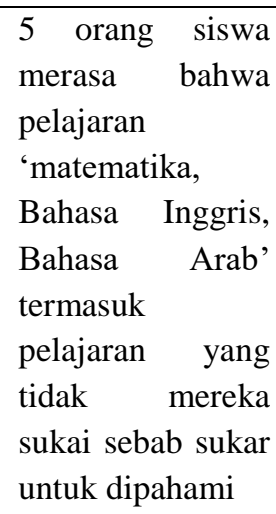 \\
\hline & & $\begin{array}{l}\text { Merasa } \\
\text { tidak } \\
\text { penting } \\
\text { dengan } \\
\text { belajar }\end{array}$ & $\begin{array}{l}\text { Semua siswa } \\
\text { menyatakan } \\
\text { bahwa belajar itu } \\
\text { penting, tetapi } \\
\text { menurut mereka } \\
\text { bukan berarti } \\
\text { kalau sudah bolos } \\
\text { maka lantas } \\
\text { menjadi bodoh }\end{array}$ \\
\hline & & $\begin{array}{l}\text { Ketidak } \\
\text { sanggupan } \\
\text { mengikuti } \\
\text { pembelajar } \\
\text { an }\end{array}$ & $\begin{array}{lr}\text { Untuk pelajaran } \\
\text { yang } & \text { sulit } \\
\text { dipahami seperti } \\
\text { matematika, } \\
\text { maka beberapa } \\
\text { siswa merasa } \\
\text { auhtak acuh } \\
\text { dengan pelajaran } \\
\text { tersebut. }\end{array}$ \\
\hline & & $\begin{array}{l}\text { kekeliruan } \\
\text { Orientasi } \\
\text { belajar }\end{array}$ & $\begin{array}{lr}3 \text { orang anak } \\
\text { beranggapan } \\
\text { bahwa tidak } \\
\text { harus dengan } \\
\text { sekolah baru } \\
\text { menggapai } \\
\text { kesuksesan, jadi }\end{array}$ \\
\hline
\end{tabular}


INTIQAD: JURNAL AGAMA DAN PENDIDIKAN ISLAM

ISSN 1979-9950 (print) || ISSN 2598-0033 (online), http://jurnal.umsu.ac.id/index.php/intiqad

DOI: 10.30596/intiqad.v\% vi\%i.4456

Vol. 12, No. 1 (June 2020)

\begin{tabular}{|c|c|c|c|}
\hline & & & $\begin{array}{lr}\text { walaupun } & \text { tak } \\
\text { masuk } & \text { sekolah } \\
\text { seseoang } & \text { tetap } \\
\text { berpeluang } & \text { untuk } \\
\text { menjadi } & \text { orang } \\
\text { sukses } & \end{array}$ \\
\hline \multirow{5}{*}{2} & \multirow{5}{*}{ Eksternal } & $\begin{array}{l}\text { Pengaruh } \\
\text { teman }\end{array}$ & $\begin{array}{l}5 \text { orang siswa } \\
\text { yang mengaku } \\
\text { bahwa kebiasaan } \\
\text { bolos sekolah } \\
\text { mereka bermula } \\
\text { dari ajakan teman } \\
\text { untuk nongkrong } \\
\text { disuatu tempat }\end{array}$ \\
\hline & & $\begin{array}{l}\text { Kecanduan } \\
\text { internet }\end{array}$ & $\begin{array}{lr}3 \text { orang } & \text { siswa } \\
\text { mengaku } & \text { setiap } \\
\text { bolos pergi untuk } \\
\text { bermain internet } \\
\text { di } \\
\text { internet. }\end{array}$ \\
\hline & & $\begin{array}{l}\text { Ketidakny } \\
\text { amanan } \\
\text { dengan } \\
\text { guru }\end{array}$ & $\begin{array}{lr}2 \text { orang } & \text { siswa } \\
\text { kerap dimarahi } \\
\text { sebab } \\
\text { mampu tidak } \\
\text { menjawab antuk } \\
\text { menyelesaikan } \\
\text { tugas atau } \\
\text { diberikan }\end{array}$ \\
\hline & & $\begin{array}{l}\text { Adanya } \\
\text { kesempata } \\
\mathrm{n} \quad \text { sebab } \\
\text { lepas } \\
\text { kontrol } \\
\text { dari } \\
\text { keluarga }\end{array}$ & $\begin{array}{l}2 \text { orang anak juga } \\
\text { mengaku bahwa } \\
\text { orang tua mereka } \\
\text { telah } \\
\text { meninggalkan } \\
\text { rumah sejak jam } \\
5 \text { pagi untuk } \\
\text { pergi berjualan ke } \\
\text { pasar. }\end{array}$ \\
\hline & & $\begin{array}{l}\text { Lingkunga } \\
\mathrm{n} \text { tempat } \\
\text { tinggal }\end{array}$ & $\begin{array}{lr}\text { orang } & \text { siswa } \\
\text { mengaku } & \text { bahwa } \\
\text { tempat } & \text { tinggal } \\
\text { mereka } & \text { marak } \\
\text { dengan anak-anak } \\
\text { yang }\end{array}$ \\
\hline
\end{tabular}

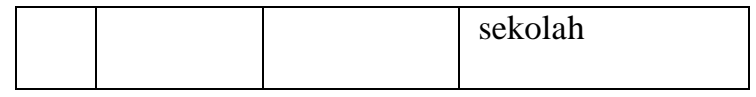

Jika dicermati hasil wawancara di atas dapatlah disimpulkan bahwa terdapat dua bentuk aspek faktor kebiasaan bolos siswa, yakni aspek psikologi dan aspek sosial siswa. Aspek Psikologi berarti yang berasal dari dorongan dalam diri siswa, sedangkan sosial berkaitan dengan pengaruh lingkungan sosial, dan perkembangan zaman. Bahkan efeknya pada diri siswa juga akan menyangkut dua aspek yakni gangguan psikologi, dan perilaku yang bertentangan dengan moral sosial. Kedua efek itu tentu akan menjadi kompleks merambat pada masalah-masalah yang lainnya.

\section{Pola Kerjasama guru PAI dan IPS dalam Menangani Perilaku Bolos Sekolah}

Pada dasarnya pelajaran PAI dan IPS merupakan dua pelajaran yang berbeda, baik dari konten maupun tujuan pembelajarannya. Pelajaran PAI memiliki karekteristik pembelajaran yang memuat ajaran-ajaran Agama Islam baik yang berkaitan dengan Akidah, Syariah dan Akhlak. Sedangkan pelajaran IPS memuat konten aktivitas sosial, bentuk hubungan sosial, dan interaksi sosial. Secara lebih spesifik 
INTIQAD: JURNAL AGAMA DAN PENDIDIKAN ISLAM

ISSN 1979-9950 (print) || ISSN 2598-0033 (online), http://jurnal.umsu.ac.id/index.php/intiqad

DOI: 10.30596/intiqad.v\% vi\%i.4456

Vol. 12, No. 1 (June 2020)

karekteristik IPS (1) interaksi, (2) saling membutuhkan dan ketergantungan, (3) berkelanjutan dan perubahan, (4) keragaman/kesamaan/perbedaan, konflik dan konsesus, (6) pola (patron), (7) tempat, (8) kekuasaan (power), (9) nilai kepercayaan, (10) keadilan dan pemerataan, (11) kelangkaan (scarcity), (12) kekhususan, (13) budaya (culture), dan (14) nasionalisme (Widiastuti, 2017).

Tetapi pada aspek kedirian dan hubungan sosial, pelajaran IPS dan PAI memiliki kesamaan, dan bahkan saling mendukung, yakni sama-sama menekankan akan pentingnya memiliki sikap sikap/akhlak yang baik baik akhlak individu maupun akhlak dalam pergaulan. Siswa yang berhasil dalam pelajaran IPS tentu memiliki sikap yang dikehendaki oleh sosial, sedangkan yang berhasil dalam pelajaran PAI ialah yang memiliki sikap yang dikehendaki agama dan sosial. PAI juga mengajarkan tentang hubungan sosial yang baik, tetapi dalam pandangan Alquran dan Hadis Sedangkan sosial mengajarkan pandangan teori-teori sosial.

Seperti yang telah disebutkan di atas bahwa sekolah yang tidak memiliki guru Konseling, maka dapat menjadikan guru PAI dan IPS sebagai sosok terdepan dalam menghantarkan siswa pada sikap-sikap yang mulia, bahkan dalam mengatasi perilaku menyimpang, seperti kebiasaan bolos yang akan dibahas secara panjang lebar. Hasil pengamatan dan wawancara penulis terhadap guru PAI dan IPS di MTs. PAI, bahwa kerja sama tersebut bermula dari tidak adanya guru konseling, kemudian menilai bahwa faktor bolos juga dipengaruhi oleh aspek sosial, sehingga muncullah kesadaran keduanya untuk bekerja sama. Dengan statement tersebut jelas bahwa kerja sama tersebut bukanlah atas perintah atau dorongan Kepala Sekolah melainkan kesadaran keduanya.

Hasil pengamatan dan wawancara diperoleh data tentang pola kerja sama yang dibangun guru PAI dan IPS, sebagai berikut.

a. Memberikan bimbingan dalam aspek social, guru IPS membimbing cara memilih teman bergaul yang baik, cara berinteraksi dan bergaul yang tepat, membentengi diri dari lingkungan yang tidak baik. Dalam aspek Pendidikan Agama Islam guru memberikan bimbingan mengenai konsep mengenali diri sendiri, adab 
ISSN 1979-9950 (print) || ISSN 2598-0033 (online), http://jurnal.umsu.ac.id/index.php/intiqad

DOI: 10.30596/intiqad.v\% vi\%i.4456

Vol. 12, No. 1 (June 2020)

bergaul yang sesuai dengan petunjuk Alquran dan Hadits.

Adapun bentuk bimbingan di MTs. PAI ini dapat dilakukan secara kolektif dan dapat juga dilakukan secara individu. Hal ini disesuaikan pada tingkatannya. Pada tingkat awal dilakukan secara individu. Jika problematika mulai meningkat, maka bimbingan dapat dilakukan secara kolektif. Hal itu dilakukan untuk lebih menguasai problmatika yang sedang dihadapi siswa dan pencarian solusinya. Mengenai tempatnya, baik guru PAI dan guru IPS menggunakan ruang perpustakaan sebagai solusi alternative untuk mereka dapat bertatap muka dalam ruang yang terbatas sehingga jauh dari kebisingan dan kekacauan.

b. Membuat program kegiatan yang berjudul 'aku malu bolos sekolah', kegiatan ini berupa seminar yang melibatkan orang tua dan siswa. Pada kegiatan ini diberikan penyuluhan tentang pentingnya pendidikan bagi masa dengan dan dampak dari tidak adanya pendidikan. Di sela-sela kegiatan ini akan diberikan penghargaan kepada siswa dan guru yang paling disiplin, kegiatan ini diprakarsai oleh guru PAI dan IPS.

c. Bekerja sama dalam mendesain formulasi materi pembelajaran tentang dampak dari perilaku bolos. Degan adanya dua perpsepektif baik sosial dan agama siswa akan lebi memahami secara kompleks tentang dampaknya. Di antara materi tentang perilaku bolos yakni manusia dan makhluk sosial, masyarakat dan perilaku menyimpang, dampak perilaku terhadap perkembagan siswa.

d. Penerapan strategi moral kognitif, maksudnya dalam hal ini guru IPS dan PAI merekayasa pembelajaran dengan menyajikan materi tentang 'bahaya bolos sekolah', dan menjelaskan akibatnya, lalu kemudian memerintahkan siswa untuk berdiskusi tentang hal tersebut dan memberikan kesimpulan kognitif tentang bagaimana sebenarnya bahaya bolos sekolah tersebut.

e. Merekayasa lingkungan dan pergaulan sekolah yang memungkinkan siswa dapat nyaman dalam berinteraksi sosial. Selama ini siswa yang memiliki kebiasaan bolos sekolah enggan untuk didekati oleh teman-temanya, maka dalam hal ini 
ISSN 1979-9950 (print) || ISSN 2598-0033 (online), http://jurnal.umsu.ac.id/index.php/intiqad

DOI: 10.30596/intiqad.v\% vi\%i.4456

Vol. 12, No. 1 (June 2020)

guru PAI dan IPS mengajarkan dan menyeru untuk tidak mendiskriminasi orang lain.

f. Membatasi pergaulan siswa. Selama ini tatkala jam istirahat terdapat beberapa siswa yang sering istirahat di luar lokasi sekolah dan tidak kembali lagi ke kelas. Dalam kerja sama guru PAI dan IPS tidaklah membenarkan hal yang demikian. Sehingga saat ini ketika jam istirahat siswa hanya boleh di dalam areal halaman sekolah.

g. Guru IPS dan PAI menjalin kerja sama dengan orang tua, dan masyarakat setempat untuk turut berperan serta dalam meminimalisasi kebiasaan membolos tersebut. Caranya dengan membuat laporan kepada pihak sekolah jika terjadi halhal yang tidak diinginkan.

h. Guru IPS dan PAI bekerja sama dalam memberikan punishment kepada siswa, hal ini agar ada keseimbangan hukuman baik dalam aspek sosial maupun agama. Guru IPS akan mempertimbangkan hukuman yang tepat secara sosial, begitu juga dengan guru PAI mempertimbangkan hukuman yang tepat secara syar'i.
Dari beberapa pola kerja sama di atas dapatlah diambil satu kesimpulan bahwa yang tidak dimiliki siswa ialah ketidakmampuan dalam memahami dampak dari bolos sekolah, sehingga pola kerja sama yang tampak lebih mengarah kepada upaya untuk membimbing pemahaman aspek sosial dan agamanya.

Di samping hal tersebut di atas, untuk dapat menangani ini dengan baik, guru terlebih dahulu harus memiliki keperibadian yang mulia. Jika tidak demikian, guru tidak akan mampu menularkan keperibadian yang mulia pula kepada perserta didiknya (Lubis, Kompetensi Kepribadian Guru Dalam Persfektif Islam, 2016).

\section{Kendala yang Dihadapi dalam Menangani Perilaku Bolos Sekolah}

Kerja sama guru IPS dan PAI tidak selamanya mulus. Ada beberapa kendala yang mereka hadapi, walaupun kendala dimaksud dapat dianggap tidak begitu berarti, diantaranya:

a. Kurangnya perhatian orang tua terhadap perilaku bolos anak tersebut. Hal ini disebabkan karena tingginya aktivitas orangtua sehingga hanya 
INTIQAD: JURNAL AGAMA DAN PENDIDIKAN ISLAM

ISSN 1979-9950 (print) || ISSN 2598-0033 (online), http://jurnal.umsu.ac.id/index.php/intiqad

DOI: 10.30596/intiqad.v\% vi\%i.4456

Vol. 12, No. 1 (June 2020)

memiliki waktu yang sedikit untuk anaknya.

b. Kurangnya keharmonisan rumah tangga, maksudnya terdapat beberapa anak yang memang sedang mengalami broken home dalam arti keluarganya terpisah sebab perceraian orang tua, yang membuat anak tinggal bersama dengan keluarga lainnya.

c. Sulitnya memberikan kesadaran kepada masyarakat setempat untuk mau bekerja sama dalam menangani perilaku ini, padahal guru PAI dan IPS telah menyebarkan nomor kontak tetapi kadang kala juga masih enggan untuk menyampaikan jika ada siswa yang tidak masuk kelas.

d. Sulitnya membagi waktu. Tidak dapat dipungkiri bahwa dalam hal ini guru IPS dan PAI sama-sama memiliki peran ganda, yakni di satu sisi ia harus mengajar mata pelajaran mereka, dan di sisi lain harus meluangkan waktu untuk dapat memberikan tenaga pada siswa yang mengalami permasalahan kehadiran.

\section{Simpulan}

Pola kerjasa sama Guru IPS dan PAI lebih mengarah pada bentuk bimbingan yang memuat integrasi formulasi materi pelajaran berbasis aspek sosial dan ajaran agama Islam. Hal itu dilakukan tentu karena minimnya dasar pengetahuan siswa tentang hal itu. Walaupun dalam kacamata penulis bahwa formulasi materi itu tidak tertera dalam buku ajar, tetapi formulasi materi itu tersampaikan secara lisan. Bentuk kerjsama ini bukanlah kerja sama abadi, dalam arti tentu hanyalah bersifat insedentil sebagai penopang ketidakberadaan konselor di sekolah tersebut. tentu jika konselor ada akan lebih terprogram dan lebih tertangani perilaku-perilaku yang demikian.

\section{E. Daftar Pustaka}

Afrilian. (2017). Upaya Mengurangi Perilaku Membolos Melalui Layanan Konseling Kelompok Behavioral Teknik Penguatan Positif Pada Siswa Kelas VIII SMP Negeri 3 Palu. Jurnal Konseling dan Psikoedukasi, 2(2), 54 .

Barni, M. (2019). Tantangan Pendidik Di Era Millennial. Transformatif, 3(1), 118.

Creswell, J. (2007). Qualitiative inquiry \& Research design; Choosing Among Five Approaches. London: Sage Oublications. 
ISSN 1979-9950 (print) || ISSN 2598-0033 (online), http://jurnal.umsu.ac.id/index.php/intiqad

DOI: 10.30596/intiqad.v\% vi\%i.4456

Vol. 12, No. 1 (June 2020)

Damayanti, F. A., \& Setiawati, D. (2013). Studi Tentang Perilaku Membolos Pada Siswa Sma Swasta Di Surabaya. Jurnal BK Unesa, 3(1), 454-461.

Destiana, N. (2016). Hubungan Cara Mengasuh Oleh Orang Tua Terhadap Perilaku Membolos Pelajar SMA. Prosiding Penelitian dan Pengabdian kepada Masyarakat, (p. 5).

Erzard, A. M. (2018). Peran Orang Tua Dalam Mendidik Anak Sejak Dini Di Lingkungan Keluarga. Thufula: Jurnal Inovasi Pendidikan Guru Raudhatul Athfal, 5(2), 414.

Jailani, M. S. (2014). Teori Pendidikan Keluarga dan Tanggung Jawab Orang Tua dalam Pendidikan Anak Usia Dini. Nadwa: Jurnal Pendidikan Islam, 8(2), 245.

Lubis, R. R. (2016). Kompetensi Kepribadian Guru Dalam Persfektif Islam. Tazkiya, 5(2), 10.

Lubis, R. R. (2018). Optimalisasi Kecerdasan Spiritual Anak. Jurnal Al-Fatih, 1(1), 4-5.

Lubis, R. R. (2018). Strategi Mendidik Akhlak Anak di Zaman Modern (Studi Pemikiran Nasih 'Ulwān Dalam Kitab Tarbiyatul Aulād). An-Nahdhah, 1(1), 59.

Lubis, R. R. (2019). Analisis Learning and Inovation Skills Mahasiswa
PAI Melalui Pendekatan Saintifik dalam Implementasi Keterampilan Abad 21. Conciencia, 19(2), 114.

Moleong, L. J. (2008). Metodologi Penelitian Pendidikan. Jakarta: Bumi Aksara.

Nata, A. (2018). Pendidikan Islam di Era Milenial. Jurnal Conciencia, 18(1), 10-28.

Novarita, E. (2014). Perilaku Bolos Siswa dan Implikasinya Terhadap Layanan Bimbingan dan Konseling (Studi Deskriptif Terhadap Siswa SMP N 1 Pasaman). Jurnal Konseling dan Pendidikan, 2(2), 9-13.

Putri, M. S., Daharnis, D., \& Zikra, Z. (2017). Hubungan Kontrol Diri dengan Perilaku Membolos Siswa. Jurnal Konselor, 1.

Rahmawati, N. (2018). Internet Addiction pada Remaja Pelaku Substance Abuse: Penyebab atau Akibat? Buletin Psikologi, 26(1), 64-70.

Salainty, \& Rondonuwu. (2015). Pengaruh Permainan Internet Terhadap Perilaku Remaja Di Kelurahan Karombasan Utara. Acta Diurna, 4(1), 4.

Siregar, F. R. (2016). Metode Mendidik Anak dalam Pandangan Islam. Forum Paedagogik, 2, 107-121. 
INTIQAD: JURNAL AGAMA DAN PENDIDIKAN ISLAM

ISSN 1979-9950 (print) || ISSN 2598-0033 (online), http://jurnal.umsu.ac.id/index.php/intiqad DOI: 10.30596/intiqad.v\% vi\%i.4456

Vol. 12, No. 1 (June 2020)

Stake, R. E. (1995). The Art Of Case Study Research. London: Sange Publications.

Widiastuti, E. H. (2017). Pemanfaatan Lingkungan Sebagai Sumber Pembelajaran Mata Pelajaran IPS. Satya Widya, 33(1), 29-36. 